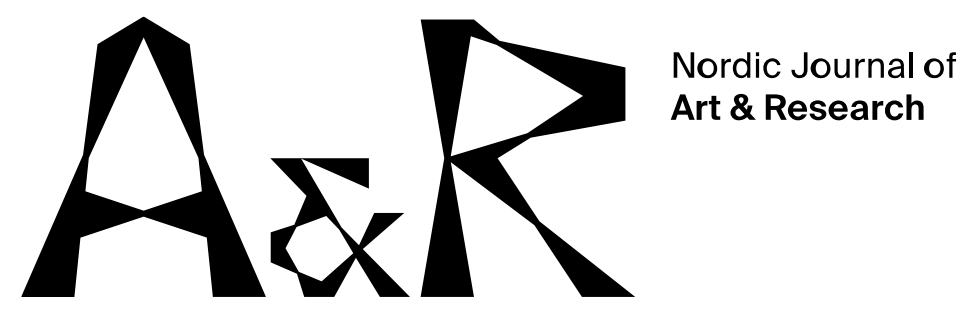

\title{
Projecto X: A Journey Inside Ourselves and What We Found When We Arrived
}

\author{
Jorge Graça ${ }^{1}$, Helena Rodrigues ${ }^{2}$, Paulo Maria Rodrigues ${ }^{3}$ \\ Universidade NOVA de Lisboa, Universidade de Aveiro \\ \& Companhia de Música Teatral
}

\begin{abstract}
This article analyses and reflects upon a community music project that occurred in 2016 in Portugal. It involved a community of people with disabilities and a group of artists from different fields. The project's promotors aimed to create a space in which differences were abated, social well-being was nourished and individual desires were fostered. This article endeavours to understand how artistic performance may provide opportunities for empowering less advantaged people and how it might have been achieved during this project. The reflections present in this article are based on the current literature on community music and are informed by other similar analysis of these kinds of projects.
\end{abstract}

The article starts with a brief description of the project and then elaborates on the term 'community music' and its relationship to this project. The project made use of a mix between an art installation and an experimental instrument called Pianoscópio. This article describes this instrument in detail and analyses how it enabled the

\footnotetext{
${ }^{1}$ CESEM - FCSH - Universidade NOVA de Lisboa, Portugal jorge.graca@campus.fcsh.unl.pt ${ }^{2}$ CESEM - FCSH - Universidade NOVA de Lisboa \& Companhia de Música Teatral, Portugal helenarodrigues@musicateatral.com

3 INET-md, DeCA - Universidade de Aveiro \& Companhia de Música Teatral, Portugal paulo.rodrigues@musicateatral.com
} 
Jorge Graça, Helena Rodrigues, Paulo Maria Rodrigues.

Projecto $X$ : A journey inside ourselves and what we found when we arrived

participants to express themselves to their fullest abilities. A characterisation of the participating community members follows, focusing on the core tenets of the association they were part of. After that, the article examines how the workshops took place and what transpired in the final performance, focusing specifically on the steps taken to accommodate the different disabilities of the participants. The article ends with a reflection upon these kinds of projects and the impact this one project might have had on its participants.

Keywords: community music, art education, accessibility, art for everyone, social inclusion

\section{Introduction}

This article explores the development of the 2016 edition of Projecto X, an artistic project that occurs in different places every year, developed by Paulo Maria Rodrigues, one of the founders of Companhia de Música Teatral. Until 2016, it involved students from the master program in music teaching from the University of Aveiro as well as members from a different local community. The brevity of the name, Projecto $X$, does not mean it is short on significance. The event occurs on June 10 , which is also the Day of Portugal, Camões, and the Portuguese communities, a national holiday. As such, Projecto $X(X=10)$ always focus on the creation of an artistic project with a community. Its creator and coordinator Paulo Rodrigues further explores the name in an interview:

' $X$ ' marks, therefore, a meeting point where, through musical experience, each participant has the opportunity to (re)build their individuality. ' $X$ ' is also an unknown, since on this confluence map the final result began as an unknown. ' $X$ ' is finally a mark on a game of human relations where there are no losers, only winners. (Rodrigues, 2014)

' $X$ ' embodies the union of different living spaces that express themselves through art. In 2014, Project $X$ included the participation of 10 inmates of two different prisons, and in 2015, it included a group of elderly people from a care home and a vocal trio from the Ukrainian community of Aveiro. In 2017, it was the focus of a master's thesis (Reis, 2017) and included the participation of disabled people from Cerci-Feira. Since 2016, the project has been an autonomous event, no longer part of the master's in music teaching in the University of Aveiro because the course where it originated was taken out of the curriculum. Nevertheless, some students continue to participate in the project as an extracurricular activity. 
Jorge Graça, Helena Rodrigues, Paulo Maria Rodrigues.

Projecto $X$ : A journey inside ourselves and what we found when we arrived

For the 2016 version, despite the change of format, seven artists (former students and other musicians, a dancer and a visual artist) were invited to participate. As usual in these kinds of projects, the community had already been contacted long before the beginning of the sessions at the Science Factory, where the project took place. Given the participants focus to gain deeper knowledge about themselves through artistic practice, the project ended up being called 'Projecto X: A Journey Inside Ourselves'. Its connection to the principles of community music were intrinsic to the workshops work but were left unspoken.

What follows is a description of the development of the 2016 edition of Project $X$, the tools that were used and the networks of interactions that sprang forth during this 'game of human relations' (Rodrigues, 2014). This article follows a format present in the current literature on community music, which contains critical reflections on similar community projects. Specifically, the authors based their analysis on the writings of Kari Veblen (Kari K. Veblen, Messenger, Silverman, \& Elliott, 2013) and Mark Rimmer (Rimmer, 2006) while analysing other community music projects that included people with disabilities (Reis, 2017).

The authors did not approach the workshops as researchers but as musicians. The reflections made upon the project were based on their utility to the authors as organisers of the project during its duration. In-depth reflection was made not only about the personal experience of the researchers, but also of recordings of the sessions and written statements from the participants shared in an institutional blog. The methodology could be called participatory observation, but one in which the data collected at first was not done for research purposes. The lead author at first only participated as a musician and the later took on the role as researcher.

Many research projects involve a great degree of methodological planning. This project was not originally conceived as a research one, and so many of its greater attributes arose organically during the project. As such, the following reflections do not take the same form of something that was completely planned beforehand. We do not see this as a shortcoming, as the lack of a research focus in the early stages of the project led to more artistic authenticity within the project and among the participants.

\section{Community Music}

An in-depth discussion about the nature of community music is not within the scope of this article. It is, however, relevant to acknowledge that the project discussed here has strong commonalities with some community music principles as well as ideas 
Jorge Graça, Helena Rodrigues, Paulo Maria Rodrigues.

Projecto $X$ : A journey inside ourselves and what we found when we arrived

advocated by various authors (Higgins, 2012; Higgins \& Willingham, 2017; K.K Veblen, 2007).

Community music is a difficult term to explain. It contains two words which themselves are hard to describe: music and community ${ }^{4}$. A similar semantic difficulty is found when referring to participatory arts, of which community music is a close relative. As Claire Bishop describes in Artificial Hells, 'this expanded field of poststudio practices currently goes under a variety of names: socially engaged art, community-based art, experimental communities, dialogic art, littoral art, interventionist art, participatory art, collaborative art, contextual art and (most recently) social practice' (Bishop, 2012, p. 1). Bishop's exploration of participatory arts reveals a broad (sometimes antagonistic) diversity of projects, approaches and taxonomies. Comparatively, community music's meaning can be quite broad, leading to a vague interpretation of its purpose, especially since it does not reference any specific kind of project. Self-titled community music projects share a common ethos while being sufficiently varied so as not to seem repetitious. However, the diffusion of community music projects around the world brings with it the need for an in-depth analysis of these projects to better understand them. On this point, Kathryn Deane and Phil Mullen write, 'It is said that the winners write history. In community music in the United Kingdom, where everyone is a winner, there are many different histories' (Deane \& Mullen, 2013, p. 25). Such a statement is applicable in almost any country where the practice exists.

In Germany, the term is contentious by itself, given the troubles in translating it. Alexandra Kertz-Welzel has explored the problematic similarity between most translations of community music and troubling practices during the Third Reich (Kertz-Welzel, 2013). Nonetheless, the relatively new appearance of the term in that country (Clausen, 2016; Josties, 2016) is very similar to the situation in Portugal. In Japan, in contrast, the term applies to a very specific practice-that is, bringing older performers of traditional music into schools (Shiobara, 2011).

A reflection on the many histories of community music also brings up a discussion concerning the role of music in human rituals. Archaeological records allow us to acknowledge the prevalence of music in most cultures as a group activity (McConachie, 2011). Nonetheless, somewhere in western history, music stopped

\footnotetext{
4 'Community' comes from the Latin com (together) and unos (the number 1; singularity): a singularity composed of the togetherness of different elements (Delanty, 2010).
} 
Jorge Graça, Helena Rodrigues, Paulo Maria Rodrigues.

Projecto $X$ : A journey inside ourselves and what we found when we arrived

being a part of the community. This eventually led to the term gaining new significance in the United Kingdom in the late 1960s. Since then, community music and community arts have accrued many different meanings, and to talk about either term without first defining the version of the term being referred to may lead to misunderstandings. Even Lee Higgins's much cited book on community music opens by proposing three different perspectives on the meaning of the term (Higgins, 2012, p. 3).

In writings about community music, it is often said that regardless the ambiguity of the term, community music projects can be defined by the common beliefs they share. This position is contested by Mark Rimmer, who notes that 'the price paid for what is, from one point of view, the catch-all utility of the term 'community music' can come in the form of uncertainty, opaqueness and, perhaps, some bewilderment for those looking in on CM from the outside' (Rimmer, 2015, p. 182). Nonetheless, the project being discussed in this article was developed on the belief that there exists a shared ethos between community music projects.

By and large, community music projects aim to show that everyone has the right and ability to make, create, and enjoy their own music. Lee Higgins highlights that these projects usually involve 'skilled music leaders, who facilitate group music-making experiences in environments that do not have set curricula. Here, there is an emphasis on people, participation, context, equality of opportunity, and diversity' (Higgins, 2012, p. 21). These projects also tend to be multidisciplinary, involving not only music but also theatre and dance. There's not a search for musical excellency, although final performances tend to be highly artistic. About the structure of the projects, Kari Veblen says that in community music projects you have 'Individuals participating in various ways from observer, to participant, to creator, to leader. One's individual responsibility to the group is reciprocated by group responsibility to the individual' (K.K Veblen, 2007, p. 7).

Writings on community music's ability to lead to social change also have a tendency to 'spill' into other fields (Hallam, Creech, Varvarigou, \& McQueen, 2012). To talk about community music's exploration of intersubjective interactions, for example, is also to touch on education and therapy because 'both are process-based experiences that rely on intersubjective exchange' (C. Bishop, 2012, p. 3). As such, music therapy is sometimes lumped together with community music. Although in theory both fields may sometimes share similar goals and/or procedures, musical therapy implies a professional specialisation and academic training that the other does not. And while much is said of the therapeutic effects of music, these are not 
Jorge Graça, Helena Rodrigues, Paulo Maria Rodrigues.

Projecto $X$ : A journey inside ourselves and what we found when we arrived

the focus of community music projects but are its (sometimes unintended) secondary effects.

Nonetheless, the long-term efficacy of these kinds of projects is questioned by various authors. Among them maybe the most prolific is Mark Rimmer, who has authored several critical analyses of community music in the United Kingdom. Rimmer (2015) talks about the lack of quantitative data that characterises most academic writing on these practices, as studies on the theme of community music are mainly case studies. It is, however, relevant to note that these projects contain complex networks of social and artistic interactions, which make collecting quantitative and statistical data much more difficult. In terms of data in this article, we use the participants personal statements registered in the blog as well as their immediate responses that were captured on video during the sessions.

Projecto $\mathrm{X}$ involved a group of musicians, a visual artist and a dancer as well as a group of people from the Pais em Rede (Parents in Network) association, which helps people with disabilities. During the workshops, there was an effort to erode hierarchical differences between the participants, musicians and teacher. As a group, we aimed to put everyone on equal footing. Artistic decisions were made not only on an aesthetic basis but also on a personal and social one. The intention was to develop a space where people with disabilities were not only participants but also integral elements of the production, without whom the project could not have happened. In these ways (and others explored further on), Project $X$ was a community music project through and through. Although there was no prearranged format for what took place, as most decisions were made organically in loco, a posterior analysis of the project shows that it took similar steps to many other community music projects: contact with a community to build rapport, followed by a period of experimental workshops, which culminated in a live performance.

\section{Companhia de Música Teatral and Pianoscópio}

Companhia de Música Teatral ${ }^{5}$ (CMT), which roughly translates to Theatrical Music Company, is a Portuguese artistic group. For a little over 20 years, the company has developed a myriad of artistic projects, performances, workshops, intensive training, publications (both books and articles), conferences and installations. Their efforts are

5 The company's page has a directory of all its different projects and can be visited at the following URL: musicateatral.com 
Jorge Graça, Helena Rodrigues, Paulo Maria Rodrigues.

Projecto $X$ : A journey inside ourselves and what we found when we arrived

marked by a keen interest in exploring the relationships and boundaries between art, education and research. In most of their projects, the aim is to, in some way or another, invite community involvement, usually through laboratory-like workshops. In those spaces, CMT endeavours to explore and promote the 'importance of musical experience and art in general for social and human development' (Companhia de Música Teatral, 2019).

As such, there was a need to organise and categorise this kaleidoscope of different projects and how they interacted with one another. From this effort, the term 'artisticeducative constellations' was born. It defines a working model and a metaphor for the vision that guides CMT. This metaphor 'provides a poetic sense of a universe yet to be discovered, as well as an objective and a strong analytical framework of different 'bodies' interacting through conceptual and aesthetic "forces" or "fields"' (P. M. Rodrigues, Lopes, Miguel, \& Rodrigues, 2019, p. 153). Of the several existing constellations, the most pertinent to this article is the AdP Constellation, of which Pianoscópio is but one part.

The AdP Constellation has at its core the Anatomia do Piano (anatomy of the piano) performance. In 2011, CMT created this performance, which aimed 'to deconstruct the instrument that may be considered the most influential in the history of Western music' (Companhia de Música Teatral, 2012). It involves two performers exploring a combination of theatre and dance, always backed by music which helps merge all the different artistic fields.

The piano is a central piece and is played not only in conventional ways but also through the use of extended techniques and a John-Cage-inspired prepared piano (Nicholls, 2002). This preparation is facilitated by using easily removable pieces, which increases the variety of possible sonorities. But the piano, as well as being the aural anchor, is also an inextricable part of the scenery, as it is 'disembowelled' by both performers throughout the performance (see ). This exploration of the 'insides' of the piano is aided by the various mechanical arms that sprout out of its soundboard, carrying different objects that are used during the performance, which gives the idea of an anatomical dissection (ergo, Anatomy of the piano).

A video camera is used to capture real time images of the performance, which are projected on a big screen. This allows the performers to explore different angles of the piano's insides, producing a wide variety of 'visual landscapes' ( $P$. M. Rodrigues et al., 2019, p. 154). The whole performance is aimed at families. At the end of the show, the audience is invited to come closer to the piano to observe it. It was during 


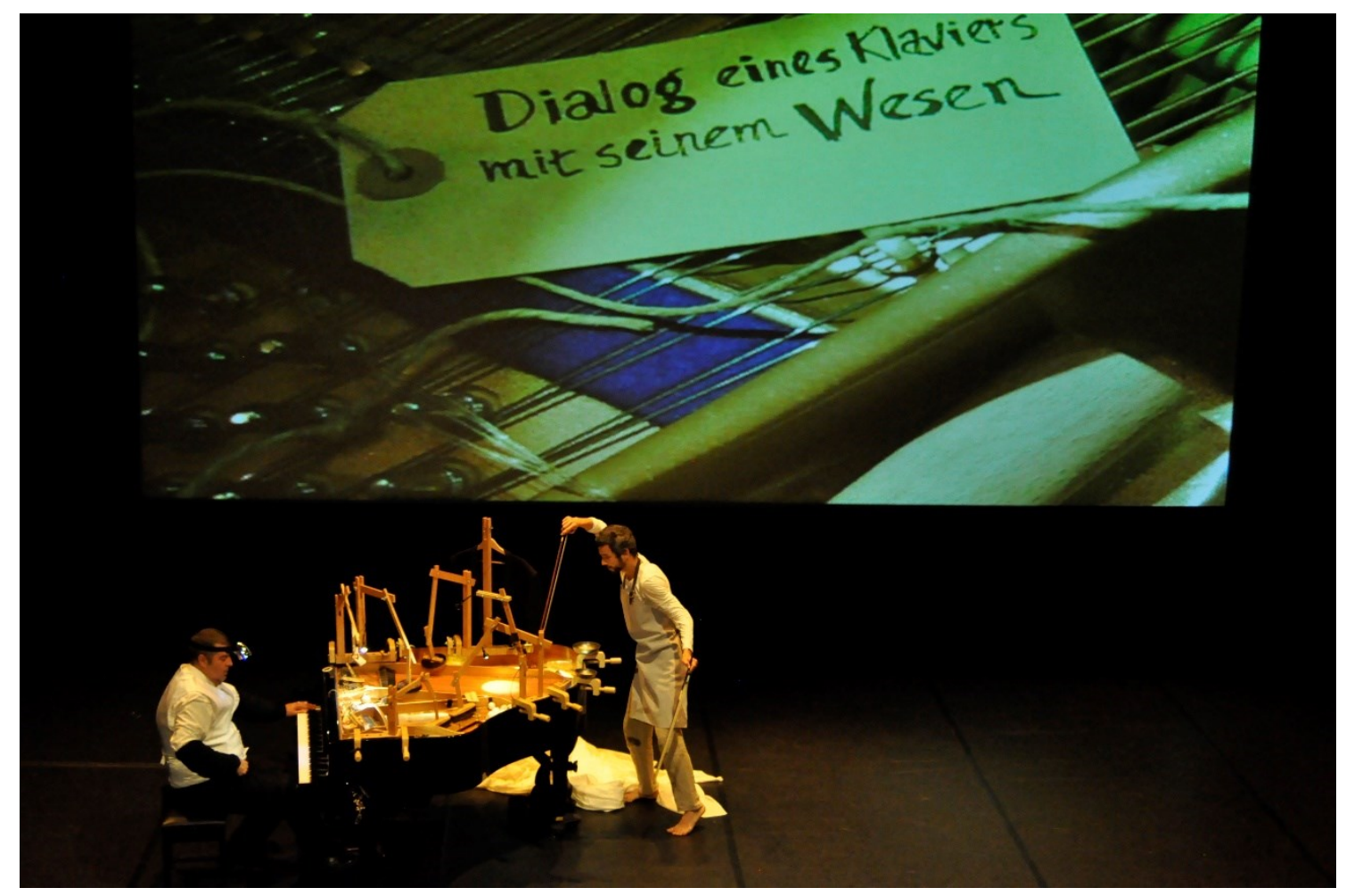

Figure 1. Still image from the Anatomia do Piano performance.

these observations that the performers noted curiosity and a desire for experimentation among the audience members. The desire to expand these experimentation spaces, which were aimed especially at children, led to the creation of Pianoscópio.

The Pianoscópio is the brainchild of a team of artists, including musicians Henrique Fernandes, Filipe Lopes, this article's third author, and visual artist Ana Guedes. A first version of the project was premiered at the BIG BANG Festival in Centro Cultural de Belém (CCB), Lisbon, in 2013. The Pianoscópio built upon the main tenets of Anatomia do Piano: the deconstruction of the piano as a catalyst for the exploration of different ways of musical discovery and expression. This was achieved by 'transforming the piano into a collective instrument, a sound exhibit/sculpture capable of producing sounds of a myriad of colours, a space to be inhabited by people and produce sound as a result of their combined interaction' (Companhia de Música Teatral, 2013). The Pianoscópio is a standard CMT project in the sense, as it lies at the intersection of performance art, education, musical creation and technological exploration.

As such, while speaking of the Pianoscópio we are referring to different but not unrelated things: 
Jorge Graça, Helena Rodrigues, Paulo Maria Rodrigues.

Projecto $X$ : A journey inside ourselves and what we found when we arrived

- an interactive exhibition composed of several pieces of dismantled pianos;

- a workshop which may last up to 60 minutes, based on the exploration of different sound elements; and

- a scenic/sound space that hosts a show that combines the resources of the exhibit with spoken voice.

This functional versatility allowed Pianoscópio to be the basis of several projects, ranging from a contemporary music $C D$ to a master's thesis.

The Fábrica de Ciência Viva (science factory) was neither the first nor the only place where the Pianoscópio resided. Nevertheless, it was the one that most fitted it, aesthetically speaking. The Pianoscópio itself is a series of wood boxes with wires, rubber balls, hammers, nuts and bolts, giant tubes with wires and other similar paraphernalia. Participants of the project noted that the hardwood floors and corrugated metal walls of the Fábrica were a perfect fit for the Pianoscópio and enhanced the laboratorial aspect of the workshops (see Error! Reference source not found.). The white jumpsuits used in the Pianoscópio performances also meshed well with the surrounding aesthetics.

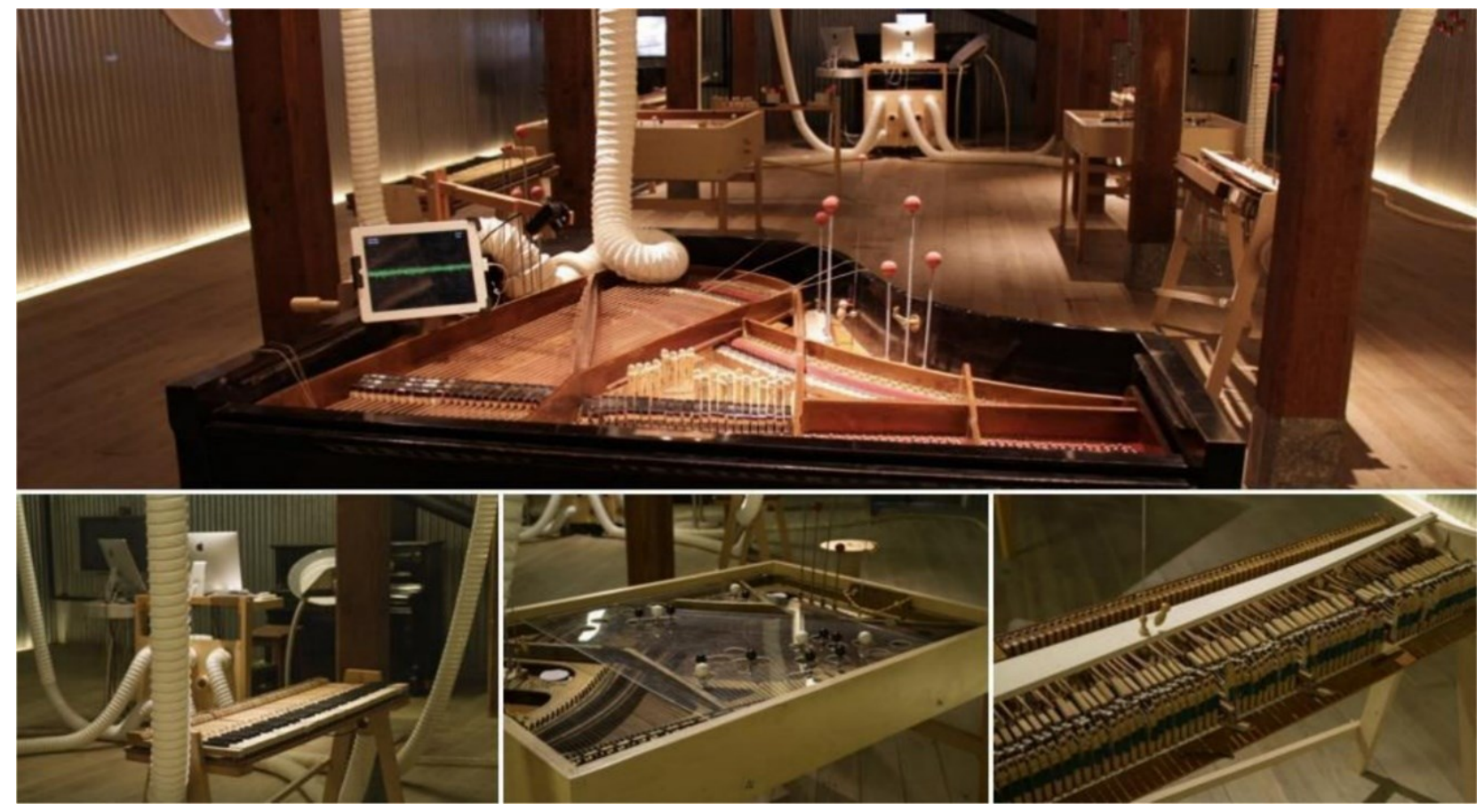

Figure 2. Different pictures of Pianoscópio at Fábrica 
Jorge Graça, Helena Rodrigues, Paulo Maria Rodrigues.

Projecto $X$ : A journey inside ourselves and what we found when we arrived

The diversity of instruments that Pianoscópio incorporates allows for more independence on the part of the performers, giving them the chance of choosing what instrument is a better fit for their abilities and desires during every step of the performance. There are plucked strings, lever-operated music boxes, keyboards, a microphone connected to a computer running a Max/Msp patch ${ }^{6}$, bowed strings (made of fishing wire and resin), percussed strings (with hammers, mallets), brushes as well as pottery birds that sing when filled with water and blown into, among other items. Every performer also carries a pre-prepared bag with a diversity of materials (including mallets, hammers, plectrums and brushes) that enable them to interact with the exhibition in different ways. The spatial distribution of the pieces also lets the performer wander not only musically but also physically (see fig. 3), choosing what piece is best for them.

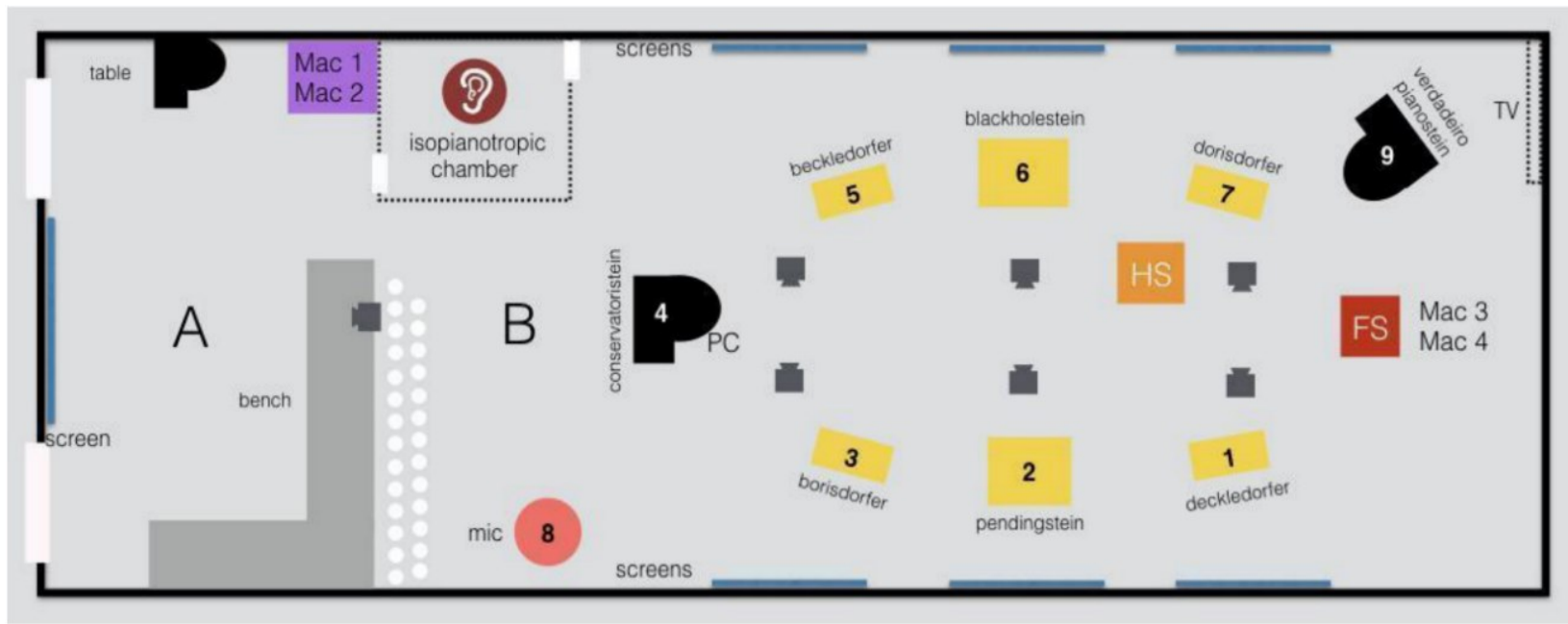

Figure 3. Layout of the Pianoscópio at Fábrica

\section{Pais em Rede and the participants}

As mentioned before, the project involved university music students and a community of disabled young adults from the Pais em Rede Association. This association was founded in November 2008 by a group of mothers that wanted to change society and promote the inclusion of children with disabilities. Now it has action centres all around Portugal, which aim to alleviate some of the challenges faced by families with children with disabilities. As it is written on the associations website, 'We know that there is a great lack of support services for families who care for a child/young/adult

\footnotetext{
${ }^{6} \mathrm{~A}$ visual programming software developed by Cycling 74 . It uses an object-oriented programming language that is easier to learn by artists and musicians. It evolved from a project created in IRCAM and is specifically tailored for use in music and visual arts. Finished programs are called patches.
} 
Jorge Graça, Helena Rodrigues, Paulo Maria Rodrigues.

Projecto $X$ : A journey inside ourselves and what we found when we arrived

with disabilities and that they face a huge variety of obstacles throughout their lives' (Pais em Rede, 2015). The association divides its work between activities aimed at entertaining and stimulating the people they help as well as taking part in politically oriented endeavours (trying to change laws, for example).

The group that participated in the project was based in Aveiro. It was led by Oksana Tymoshchuk, who was the main caretaker of this location's association. In every workshop, a few new people came and went, according to their availability, as the group's activities were always voluntary. The number of participants in the workshops varied between seven and fifteen, all with different disabilities (ASD, Down's Syndrome, blindness, to name a few), but a stable group of thirteen regularly attended the sessions and participated in the final performance. Pais em Rede mostly works with young adults who have finished their mandatory education $\left(12^{\text {th }}\right.$ year of school - 18 years old). As such, almost all participants from the association were of the same age as the musicians.

Part of the challenge in working with this group of people was the need to develop different artistic activities that did not exclude anyone based on their abilities or handicaps. Usually it didn't involve simplifying the moments as much as diversifying the performance so that everyone who wished got to participate in a special moment. Our focus was not simply allowing everyone to be a passive participant; instead, we wanted everyone to participate to the fullest of their abilities. More on this in the next section.

The development of this project would have stopped in the early stages had it not been for the frequent interactions with Tymoshchuk, who provided much feedback after the workshops and sought to simplify logistic as much as possible. While different authors emphasise the administrative and communicative skills a community musician needs to have to interact with the affected community (Higgins, 2012; McKay \& Higham, 2012; K.K Veblen, 2007), they often neglect the importance of constant and healthy communication with community representatives. Tymoshchuk's mediation in most interactions allowed for the frictionless accommodation of participants' needs and wants, allowing the flow of creativity throughout the whole workshop to be maintained.

Participation in this project was voluntary. The research methods were not invasive, and the authors heeded the counselling of not only Tymoshchuk but the other caretakers of the association as well as the family members of the participants. The 
Jorge Graça, Helena Rodrigues, Paulo Maria Rodrigues.

Projecto $X$ : A journey inside ourselves and what we found when we arrived

authors were authorised to use the real names of the participants and chose to use only the first name of each.

\section{The Workshops}

The workshops were about three hours long; the first half involved everyone, whereas the second half involved just the invited artists. They tended to be based on improvisation as well as the exploration of different kinds of musical material; the participants used their own voices and homemade instruments so that everyone could contribute to the best of their ability. The music material used to mediate these interactions was chosen both by the musicians and by speaking with the participants, which allowed everyone to feel an emotional connection with the material being worked on. Care was also taken to accommodate the different visible and invisible disabilities of the participants.

In a chapter boldly titled 'Disabling music performance', Blake Howe says, 'just as architectural features of society have the potential to exclude and stigmatise bodily difference, so too do the conventions of music performance frame certain actions, behaviours, and appearances as disabling' (Howe, 2016, p. 191). Stairs and narrow doors may disable the movement of some bodies. Similarly, certain conventions of music performance have the power to exclude. The canon and tradition of music performance imply a specific body shape of the performer. In that way, those requirements are inherently exclusionary to deviations from the norm if not properly adapted. Furthermore, participation in ensembles can negate or minimise the efficacy of adaptations made for a single performer. As Howe says, 'To participate in an ensemble, to participate in a conformational musical tradition, the excluded performer must silence disability' (Howe, 2016, p. 201).

Nonetheless, with enough accommodation, these barriers can be neutralised or reversed. One such accommodation can be performance without sheet music. Performers in such cases have the option to freely shape their performance around the specific features of their bodies. The same can be said by using adapted instruments-imposing the form of the body of the performer on the instrument and not the other way around.

All the workshops took place in the Pianoscópio to explore its limitations and possibilities in making other types of music (with a greater variety of bodies and people). As an added benefit, the Pianoscópio also provided a stable point of reference for the participants, instilling in them a sense of familiarity and continuity. This was much needed for the few participants that had an autism spectrum disorder. 
Jorge Graça, Helena Rodrigues, Paulo Maria Rodrigues.

Projecto $X$ : A journey inside ourselves and what we found when we arrived

Also, the tools provided by Pianoscópio weren't easily available anywhere else we had access to. The variety and adaptability of the instruments that integrate the exhibition also allowed us to be more hands-off and give room for everyone to find their preferred mode of expression.

There are clear challenges when working with people with disabilities. The formal characteristics of the project had to be malleable to better adapt to the rising needs of everyone, which led to some instability and unpredictability in the preparation of the final performance. The fluctuating number of participants also contributed to some of that instability. Participants were heterogeneous not only in their respective relationship to music but also in relation to language abilities and interpersonal interactions.

Special attention was given to how the power imbalances that arose from the differences in the participants' abilities and those of the musicians could be neutralised or even subverted. There was no ethics board to consult, but the authors were in constant communication with the participants; caretakers and families to avoid unconscious exploitation. In the end, some of the decisions of the participants were made by third parties (such as caretakers and family members). Those decisions create inherent asymmetrical relations, which have to be dealt with sensibly and with care.

Understandably, there were imbalances among the participants in terms of ability, and the final word on some artistic matters had to be relegated to the musicians. But there was an effort to be aware of the power differences between the musicians and the participants. That way, the participants' voices could be heard on an equal footing. And although awareness by itself will not prevent the negative effects of an unequal relationship, it can help delineate work practices that promote shared values and interests (Reid \& Frisby, 2008).

Several authors have studied how critical reflection is a valuable tool in research involving disadvantaged communities (Barton, 1996; Dalton \& McVilly, 2004; Delman, 2012; Gustafson \& Brunger, 2014; Howe, Jensen-Moulton, Lerner, \& Straus, 2016; Jeffress, 2017) while also alerting researchers of the dangers of disregarding people's abilities because of their disabilities. In the case of young people, that act is called 'adultism', and is the 'attitude that young people have little or nothing of value to offer to older adults, who then act on behalf of young people or disregard them' (Delman, 2012, p. 232). As such, those considerations may lead researchers to be 
Jorge Graça, Helena Rodrigues, Paulo Maria Rodrigues.

Projecto $X$ : A journey inside ourselves and what we found when we arrived

overly protective of the communities they study. Diana Gustafson and Fern Brunger warn of the following:

Attempts by the authors of ethics guidelines to address the potential for harm and abuse of power imbalances in research has inadvertently reentrenched conceptualizations of some populations as vulnerable, disadvantaged, and in need of protection rather than as potential partners in research about their communities (Gustafson \& Brunger, 2014, p. 1000).

Project leaders made an effort not to diminish or discredit the participants' ability to participate, as they maintained clear communication with everyone involved and strove to abide by the key principles of working with people with disabilities (Delman, 2012). The following paragraphs will explore the format of the workshops and will reflect on its efficacy.

The sessions with only the invited artists provided the opportunity for the musical material to be prepared beforehand so that its adaptation to the participants' needs could be faster and not break the participants' creative flow. Sheet music was available, although most of the musical creation was improvised and context sensitive. Most of the performed pieces ${ }^{7}$ were chosen because they were already known by most of the participants. Any request was considered, when possible. The final forms of the performed pieces were the result of processes, such as collages, arrangements, citation/exploration of musical excerpts and so on. The musical territories that were explored varied; sometimes they seemed opposed, but they always pertained to the shared aesthetics of the group and to the expansion of the borders of each musician's comfort zone. The journey through those territories passed through contemporary music (that is, spectral, textural and atonal), rock, pop, traditional, classical, tango, and other less defined forms. Instruments were also as diverse as the musical styles: voice, piano, flutes, saxophone, drums, bagpipes, Max/Msp electronic instruments and more.

As stated before, Tymoshchuk's intervention in mediating the interactions between the invited artists and the community was key to maintaining the rhythm of the workshops, and the participants state of flow. Mihaly Csikszentmihalyi in 1990

\footnotetext{
7 This term is used here for the sake of brevity; it pertains to a vast variety of different forms and styles of musical material used in the project.
} 
Jorge Graça, Helena Rodrigues, Paulo Maria Rodrigues.

Projecto $X$ : A journey inside ourselves and what we found when we arrived

described the characteristics of this frictionless and intense involvement with the task at hand, which arises in what he calls an optimal experience: 'people become so involved in what they are doing that the activity becomes spontaneous, almost automatic; they stop being aware of themselves as separate from the actions they are performing' (Csikszentmihalyi, 1990, p. 53). This loss of self-consciousness and temporal awareness - where one feels a sense of total control, effortlessness, and complete concentration on the immediate situation (the here and now) -is called flow. In general, this state arises when one's skills are fully utilised and equal to the demands of the task. This state of mind is thought to enhance inherent motivation and creativity. However, if attention is directed away from the task at hand, such benefits may be affected (L. Bishop, 2018).

Tymoshchuk's intervention maintained the group's flow, enabling continuous creative output from the group. Adaptation between performers is essential, as it allows this state to be achieved not only as a group but also by each individual. The line between something being too hard or too easy is a slim one, and in the context of this group, this line was ever-changing.

Many of the best ideas were given by the participants, not the musicians. For example, Tiago loved to sing in French, and he did it so well that we had to have him sing in French. Fábio was visually impaired and played the piano beautifully. He specifically loved to play The House of the Rising Sun, so of course it had to be part of the final performance. Carolina loved to dance, so we included a tango for her to dance with Suzanna. Suzanna was a choreographer/dancer that usually worked with the Pais em Rede Association and was very good in helping someone use their body in artistic ways, no matter what difficulties they may have. Most interaction with Pianoscópio itself was through the use of the variety of tools that were in the tote bags every participant carried (for example, hammers, mallets and brushes). These tools were used on the strings of the dismantled pianos. The interactions occurred both through guided rhythmic exercises, as well as through improvisation and textural exploration with minimal input given by the artists. A microphone was used in some pieces, allowing vocal expression and exploration; the singing was sometimes raw and sometimes accompanied with added reverb, delay and chorus. There were also some disembodied keys that through amplification and electronic distortion allowed anyone to play a variety of ethereal percussive sounds.

Most of the workshops involved being aware of the needs and musical tastes of the participants and adapting to them. On the walls, there was a projection that was a distortion of something being captured by a camera. The projection was programmed 
Jorge Graça, Helena Rodrigues, Paulo Maria Rodrigues.

Projecto $X$ : A journey inside ourselves and what we found when we arrived

by the first author in Max/Msp and used the cameras placed in various locations of the Pianoscópio. The artists found that there needed to be some visualisation of the participants' movement, since some of the most precious moments in the workshops happened when the participants used their body in creative ways. The projections were a way of guiding the stare of the participants and of the public; they highlighted the different types of movements possible.

The workshops not only included music but also dance, theatre, drawing and painting. There was an effort to create a multidisciplinary experience, so every area included an expert who would help us when our knowledge failed. Most of the times, the experts were also already acquainted and collaborating with the community.

Suzanna helped with the dancing, Tânia with the visual arts. The rest played as many instruments as required to set the mood. Many times, the musicians played instruments they had never played before.

One constant during the workshops was the use of the body through improvisation. In the same way that different voices can contribute to the same choir, different bodies contribute to a singular choreography. With that in mind, the body of every participant was used as much as their voices and as much as the tools of the Pianoscópio. Improvisation paved the way for the blending of different contributions, allowing the participants to exteriorise their own artistic vision while conforming to pre-established aesthetic principles, which strengthened the social interactions within the group. As Lee Higgins and Roger Mantie state, 'while there is an undeniable skill and musicianship aspect to improvisation, improvising — like all forms of music-making is a social act' (Higgins \& Mantie, 2013, p. 41).

Throughout the project, an important aspect of communication was the use of a blog ${ }^{8}$, whose usefulness cannot be overstated. It allowed the participants to share their thoughts and reflections instantly to everyone. That facet was especially useful given that in 2016 not everyone had a smartphone, and almost none of the involved used group text apps. The blog allowed the sharing of photos and videos of the workshops for posterior artistic improvement and archival. It enabled deep reflections upon some of the more controversial situations in an open forum-like format. And given that the blog still exists, it has been used subsequently in other iterations of Project $X$, acting now as a knowledge base ready to inspire future projects. In a very

\footnotetext{
8 This blog was private, which helped not only maintain the safety and privacy of the participants but also led to greater intimacy and closeness of communication.
} 
Jorge Graça, Helena Rodrigues, Paulo Maria Rodrigues.

Projecto $X$ : A journey inside ourselves and what we found when we arrived

pragmatic way, the blog was useful for cutting down conversations before and after the workshop, leaving more time for practical experimentation.

The contributions to the blog highlighted something that most of the participants agreed was significant: that everyone was happy during the workshops, and that the relationships between the participants were that of friendship and comradery, with no-one being left out, and everyone participated to the best of their abilities during every step of the performance, be it dance, music or poetry. As Mark Rimmer has pointed out, sometimes these kinds of projects can focus too much on skill acquisition and not so much on giving the participants space for their own creativity (Rimmer, 2009, p. 86).

\section{The Performance}

The performance was public; reservations were needed, as there was limited seating. Priority was given to the families of the participants. As much as possible during the performance, there were planned and unplanned interactions with the audience. Impromptu dance moments took place. Great importance was given to the social and personal well-being of the participants while striving for higher artistry.

There was a rough draft of a script, with general indications about the performance's different parts. It was printed out and handed to the musicians and caretakers, but it did not include notes or lyrics, only brief descriptions: 'game of the plastic bags. Fábio on the keyboard, House of the Rising Sun, two chorus alternating with improv Am. Duo Carolina and Suzanna. Voices in the last two chorus', or even less like 'Parade (G mixolydian)'. The rest of the communication during the performance was nonverbal, with everyone being very focused on what was happening around them and responding dynamically and organically to all the musical cues given by Paulo, the other musicians or the participants. There was maximum freedom given to everyone, so surprises were bound to happen. Most musical interventions by the part of the musicians were context sensitive. The helpers from the association had an essential role in allowing the musicians to focus on specific musical tasks during the performance, therefore contributing to the flow of the performance.

Some participants recorded the performance and shared them on the blog. In the end, there was a great sense of gratefulness from both the participants and their families. 
Jorge Graça, Helena Rodrigues, Paulo Maria Rodrigues.

Projecto $X$ : A journey inside ourselves and what we found when we arrived

\section{A Journey Inside Ourselves}

The project provided the opportunity for people with special needs to become deeply involved in the creation and public presentation of a multimedia performance of music and dance, aided by the various teachers, caretakers and students. The result was an emotionally powerful performance that exhibited a high level of artistry from everyone involved. The musicians, most studying to be music teachers, all left the project with a great assortment of tools to use in many situations and with the inspiration to pursue these kinds of endeavours. Testimonies on the blog corroborated that the project created a safe space and let the participants from the community to be as productive and insightful as anyone else, giving everything they could with the limitations they had. The project would not exist without their precious contributions. Participants approached the musicians as colleagues, and those interactions were reciprocated by the musicians on an equal level of familiarity.

Although researchers argue that these kinds of projects are important and relevant, talking and thinking about them are still necessary, at least in Portugal. There, as in Norway (Rinde \& Schei, 2017), these kinds of practices predated the coining of the term 'community music' but were rarely the focus of academic studies. Recently, though, this tendency has changed. And although now there is more parity between the quantity of projects and the reflections upon them, both are still low when considering how much the communities are affected by these kinds of projects and how rare they are in their life.

Portugal has been inconsistent when it comes to its treatment of citizens with disabilities. Successive governments have been on the forefront of the adoption of good practices. The Convention on the Rights of Persons with Disabilities was signed and ratified in Lisbon (United Nations General Assembly, 2006), bringing with it new laws to help in its application. Yet other authors have noted a large gap between what was written in the legislation and what has actually been put into practice (Sousa, Casanova, \& Pedroso, 2007).

These kinds of artistic projects may help create the bridge between what should be done to help people with disabilities, and what can be done. With the start of the $21^{\text {st }}$ century, it has become harder and harder to deny the ability of art to empower society's most disadvantaged and marginalised (Laes, 2015; Wallace-DiGarbo \& Hill, 2006). The term 'community arts' (and by extension 'community music') is imbued with the meaning of social change. Arts give the silenced a chance to make themselves heard. Of course, art itself cannot be the whole engine of social change, but it is an important catalyst (Bergh, 2007). Nonetheless, community artists still 
Jorge Graça, Helena Rodrigues, Paulo Maria Rodrigues.

Projecto $X$ : A journey inside ourselves and what we found when we arrived

thrive to enhance the lives of the communities with whom they interact (McKay \& Higham, 2012).

However, we should be aware of the shortcomings of such conclusions. As musicians and as scholars, much reflection is needed about the impact of such endeavours on the participants. Maybe, as Arild Bergh poses, 'attempts to isolate aesthetic experiences and harness their potential for emotional affect without connecting them to the daily life of participants just emphasises [sic] their short lived nature, and has little effect' (Bergh, 2007, p. 146). Since there was no call for an indepth study of this project and its impact on the participants, we are now confronted with a lack of adequate materials for reflection.

Now, almost four years after this project's conclusion, what echoes remain? Although much can be learned for what the project was and how it came to be, there is also much that is left to be said, especially concerning the inner worlds of the participants. These reflections should not be the only focus on these kinds of projects, but they should not be the exception either. Some questions arise not only in this project but also in community arts more generally. What does impact mean when we talk about these kinds of projects? Is impact something that forever changes the lives of the participants? Is it something that everyone in the same way, or is it more personalised? Did the project have less impact because it affected less people, even if those it did affect were profoundly moved? Did it have more impact because everyone said it changed them, even if in a miniscule way? What about the changes that the participants didn't even notice? What about the effects that only show themselves years after the project's completion, in a way that nobody could trace to their origins? There's a deeper discussion about evaluation of artistic projects impact beginning to take place in scientific discourse, and future projects should be aware of it.

François Matarasso (Lowe \& Matarasso, 2015; Matarasso, 1996, 1998) is at the forefront of community arts impact evaluation in the United Kingdom. His approach to evaluating these kinds of projects involves the use of outside observers as critics. Claire Bishop has shown her frustrations with the lack of 'foreclosure of critical distance in these curatorial narratives', although she admits that 'in staging multiple visits to a given project, this fate increasingly also befalls the critic' (C. Bishop, 2012, p. 6). For the time being, case study seems to have few alternatives, given that these kinds of projects often emphasise process over measurable results. In Bishop's analysis, these projects tend to focus on invisible networks: group dynamics, social 
Jorge Graça, Helena Rodrigues, Paulo Maria Rodrigues.

Projecto $X$ : A journey inside ourselves and what we found when we arrived

interactions as well as 'a change of energy, a raised consciousness' (p. 6). As a result, they depend on first-hand experience and must happen over a long duration.

The reflections outlined in this article may be relevant for those that work with people with disabilities, specifically those that aim to enable meaningful interactions between subjects and music. Such interactions may be mediated by creating open spaces for exploring and improvising, by being attentive regarding each participant's internal artistic and personal desires, by keeping the project malleable and open to change and by adapting to new circumstances as they arise. And although no group of people is the same as another, the format of incorporating caretakers, teachers and families in the project seems to be a fruitful one. Projects like the one described in this article enable people with less access to artistic practice to develop their creativity in a safe space. Not only can our reflections be useful in these kinds of associations, but they can also adapted for other contexts, such as schools, nursing homes, prisons, hospitals and pre-schools. Using a private blog for communication is also a good practice and can lead to greater intimacy and better communication among the participants of a particular project.

Project $X$ has been a source of reflection and evolution. The project's 2017 iteration had a similar approach, and its results were recorded as part of a student's master's thesis (Reis, 2017). The 2014 and 2015 versions were discussed in a student's PhD project (Lopes, 2017) as well as in a journal article (Lamela \& Rodrigues, 2016).

Project $X$ took place again in 2017 and in 2018, with different groups of people and in different spaces but with the same intention: to provide a space where differences are abated, social well-being are nourished and individual wishes and desires are fostered. A Journey Inside Ourselves.

\section{About the authors}

Jorge Graça is currently a Musical Sciences PhD student at the Faculty of Human and Social Sciences in Lisbon. His research is focused on Community Music. He obtained his master's degree in Music Teaching (Saxophone) at the University of Aveiro (2016). He taught Saxophone, Chamber Music and Electronic Music at the David de Sousa's Music Conservatorium in Figueira da Foz from 2014 until 2020. He's a saxophonist and composer and currently 4 focuses on solo electronic music projects and technology-mediated performance. He regularly collaborates with Companhia de Música Teatral. 
Jorge Graça, Helena Rodrigues, Paulo Maria Rodrigues.

Projecto $X$ : A journey inside ourselves and what we found when we arrived

Helena Rodrigues is an Assistant Professor at NOVA School of Social Sciences and Humanities, Univeridade NOVA de Lisboa, and the founder of Laboratory for Music and Communication in Infancy of the research unit CESEM at the same institution. She was a Research Fellow at Royal Flemish Academy of Belgium for Science and the Arts. She has been a disseminator of Edwin Gordon's music learning theory in Portugal since 1994. She is also one of the founders of Companhia de Música Teatral, a group that has specialized in creating artistic and educative projects that have Music at the root of interdisciplinary practice.

Paulo Maria Rodrigues is a composer, performer, artistic director and educator. With Companhia de Música Teatral he has developed many artistic and educational projects, exploring the intersection of music and other artistic languages and technology, and addressing the idea of art has a tool human development. Between 2006 and 2010, as Coordinator of Educational Services of Casa da Música, he was responsible for conceiving and implementing a vast and eclectic program of activities, including projects for the disabled, communities, schools and families. He was Visiting Professor at the School of Arts of the Catholic University of Porto, Associate Researcher at the Advanced Planetarium Collegium and is currently an Assistant Professor in the Department of Communication and Art at the University of Aveiro.

\section{References}

Barton, L. (Ed.). (1996). Disability and society: Emerging issues and insights. Longman.

Bergh, A. (2007). I'd like to teach the world to sing: Music and conflict transformation. Musicae Scientiae, 11(2_suppl), 141-157. https://doi.org/10.1177/10298649070110S207

Bishop, C. (2012). Artificial hells: Participatory art and the politics of spectatorship. Verso.

Bishop, L. (2018). Collaborative musical creativity: How ensembles coordinate spontaneity. Frontiers in Psychology, 9, 1285.

https://doi.org/10.3389/fpsyg.2018.01285

Clausen, B. (2016). Blank spaces: In search of community music in Germany. International Journal of Community Music, 9(1), 77-82.

https://doi.org/10.1386/ijcm.9.1.77 1

Companhia de Música Teatral. (2012). Anatomia do Piano. Retrieved 18 April 2020, http://www.musicateatral.com/anatomiadopiano

Companhia de Música Teatral. (2013). Pianoscópio. Retrieved 12 August 2019, from http://www.musicateatral.com/pianoscopio 
Jorge Graça, Helena Rodrigues, Paulo Maria Rodrigues.

Projecto $X$ : A journey inside ourselves and what we found when we arrived

Companhia de Música Teatral. (2019). Mil Pássaros - Mil Pássaros, Mil Lugares.

Retrieved 18 April 2020, from http://milpassaros.com/

Csikszentmihalyi, M. (1990). Flow: The Psychology of Optimal Experience (1st ed.). HarperCollins Publishers.

Dalton, A. J., \& McVilly, K. R. (2004). Ethics guidelines for international, multicenter research involving people with intellectual disabilities1,2,3,4. Journal of Policy and Practice in Intellectual Disabilities, 1(2), 57-70.

https://doi.org/10.1111/j.1741-1130.2004.04010.x

Deane, K., \& Mullen, P. (2013). Community music in the United Kingdom. In Kari K. Veblen, Stephen J. Messenger, Marissa Silverman \& David J. Elliott (Eds.), Community Music Today (pp. 25-40). Rowman \& Littlefield Education.

Delanty, G. (2010). Community (2nd ed). Routledge. https://doi.org/10.4324/9780203877050

Delman, J. (2012). Participatory action research and young adults with psychiatric disabilities. Psychiatric Rehabilitation Journal, 35(3), 231-234. https://doi.org/10.2975/35.3.2012.231.234

Gustafson, D. L., \& Brunger, F. (2014). Ethics, 'vulnerability', and feminist participatory action research with a disability community. Qualitative Health Research, 24(7), 997-1005. https://doi.org/10.1177/1049732314538122

Hallam, S., Creech, A., Varvarigou, M., \& McQueen, H. (2012). Perceived benefits of active engagement with making music in community settings. International Journal of Community Music, 5(2), 155-174.

https://doi.org/10.1386/ijcm.5.2.155 1

Higgins, L. (2012). Community music: In theory and in practice. Oxford University Press.

https://doi.org/10.1093/acprof:oso/9780199777839.001.0001

Higgins, L., \& Mantie, R. (2013). Improvisation as ability, culture, and experience. Music Educators Journal, 100(2), 38-44.

https://doi.org/10.1177/0027432113498097

Higgins, L., \& Willingham, L. (2017). Engaging in community music: An introduction. Routledge.

https://doi.org/10.4324/9781315637952

Howe, B. (2016). Disabling music performance. In Blake Howe, Stephanie JensenMoulton, Neil William Lerner \& Joseph Nathan Straus (Eds.) The Oxford handbook of music and disability studies (pp. 191-209). Oxford University Press. https://doi.org/10.1093/oxfordhb/9780199331444.013.30 
Jorge Graça, Helena Rodrigues, Paulo Maria Rodrigues.

Projecto $X$ : A journey inside ourselves and what we found when we arrived

Howe, B., Jensen-Moulton, S., Lerner, N. W., \& Straus, J. N. (Eds.). (2016). The Oxford handbook of music and disability studies. Oxford University Press. https://doi.org/10.1093/oxfordhb/9780199331444.001.0001

Jeffress, M. S. (Ed.) (2017). Pedagogy, disability and communication: Applying disability studies in the classroom. Routledge.

https://doi.org/10.4324/9781315399423

Josties, E. (2016). 'Community music' in Germany? An attempt to untangle German and English concepts in the context of music and pedagogy. International Journal of Community Music, 9(1), 23-33.

https://doi.org/10.1386/ijcm.9.1.23 1

Kertz-Welzel, A. (2013). Internationalizing and localizing: Shaping community music in Germany. International Journal of Community Music, 6(3), 263-272. https://doi.org/10.1386/ijcm.6.3.263 1

Laes, T. (2015). Empowering later adulthood music education: A case study of a rock band for third-age learners. International Journal of Music Education, 33(1), 51-65. https://doi.org/10.1177/0255761413515815

Lamela, I., \& Rodrigues, P. M. (2016). Understanding leadership in community music-making projects behind bars: Three experiences in Portuguese prisons. International Journal of Community Music, 9(3), 257-271. https://doi.org/10.1386/ijcm.9.3.257 1

Lopes, M. I. B. L. da S. (2017). Reclusão e experiência musical: A prática de piano em contexto Prisional [Unpublished doctoral dissertation]. Universidade de Aveiro.

Lowe, T., \& Matarasso, F. (2015). TIME TO THINK: An approach to peer reflection for artists and practitioners in participatory arts [Research Report]. Helix Arts.

Matarasso, F. (1996). Defining values: Evaluating arts programmes. Comedia.

Matarasso, F. (1998). Use or ornament?: The social impact of participation in the arts. Comedia.

McConachie, B. (2011). An evolutionary perspective on play, performance, and ritual. TDR: The Drama Review, 55(4), 33-50. https://doi.org/10.1162/DRAM a 00120

McKay, G., \& Higham, B. (2012). Community music: History and current practice, its constructions of 'community', digital turns and future soundings, an Arts and Humanities Research Council research review. International Journal of Community Music, 5(1), 91-103.

https://doi.org/10.1386/ijcm.5.1.91 1 
Jorge Graça, Helena Rodrigues, Paulo Maria Rodrigues.

Projecto $X$ : A journey inside ourselves and what we found when we arrived

Nicholls, D. (Ed.). (2002). The Cambridge companion to John Cage. Cambridge ; New York: Cambridge University Press. https://doi.org/10.1017/CCOL9780521783484

Pais em Rede. (2015). A Nossa História. Retrieved 29 January 2020, from Pais-EmRede website: http://paisemrede.pt/sobre-nos/a-nossa-historia/

Reid, C., \& Frisby, W. (2008). Continuing the Journey: Articulating Dimensions of Feminist Participatory Action Research. In The Sage handbook of action research: Participative inquiry and practice (2nd Ed, pp. 93-105). London: SAGE Publications. https://doi.org/10.4135/9781848607934.n12

Reis, M. S. (2017). Viagem à Fragilândia: Um projeto comunitário com pessoas da Cerci-Feira [Unpublished master's thesis]. Universidade de Aveiro.

Rimmer, M. (2006). Songs in the key of life: The musical habitus and young people's community music participation [Unpublished doctoral dissertation]. University of Newcastle.

Rimmer, M. (2009). 'Instrumental' playing? Cultural policy and young people's community music participation. International Journal of Cultural Policy, 15(1), 71-90.

https://doi.org/10.1080/10286630802682193

Rimmer, M. (2015). 'Doing what needs to be done': Understandings of UK-based community music - reflections and implications. International Journal of Community Music, 8(2), 179-195. https://doi.org/10.1386/ijcm.8.2.179 1

Rinde, F. B., \& Schei, T. B. (2017). Towards an understanding of community music in Norway. International Journal of Community Music, 10(1), 19-31. https://doi.org/10.1386/ijcm.10.1.191

Rodrigues, P. (2014, June 5). Concerto do Projeto X celebra música feita num espírito de comunidade. Universidade de Aveiro - Notícias. Retrieved from http://www.ua.pt/pt/noticias/0/38582

Rodrigues, P. M., Lopes, F., Miguel, M., \& Rodrigues, H. (2019). Looking at music, science and education through the pianoscope. Proceedings of Research Hands on PIANO — International Conference on Music Performance, 152164. University of Aveiro.

Shiobara, M. (2011). Transferring community music into the classroom: Some issues concerning the pedagogy of Japanese traditional music. International Journal of Community Music, 4(1), 29-37.

https://doi.org/10.1386/ijcm.4.1.291 
Jorge Graça, Helena Rodrigues, Paulo Maria Rodrigues.

Projecto $X$ : A journey inside ourselves and what we found when we arrived

Sousa, J., Casanova, J. L., \& Pedroso, P. (Eds.). (2007). Mais qualidade de vida para as pessoas com deficiências e incapacidades - Uma estratégia para Portugal. CRPG - Centro de Reabilitação Profissional de Gaia.

United Nations General Assembly. Convention on the Rights of Persons with Disabilities, A/RES/61/106 § (2006).

Veblen, Kari K., Messenger, S. J., Silverman, M., \& Elliott, D. J. (Eds.). (2013). Community Music Today. Rowman \& Littlefield Education.

Veblen, K.K. (2007). The many ways of community music. International Journal of Community Music, 1(1), 5-21.

https://doi.org/10.1386/ijcm.1.1.5 1

Wallace-DiGarbo, A., \& Hill, D. C. (2006). Art as Agency: Exploring Empowerment of At-Risk Youth. Art Therapy, 23(3), 119-125.

https://doi.org/10.1080/07421656.2006.10129627 